\title{
FIRST RECORD OF THE MITE GENUS RACKIA (ACARI: HETEROSTIGMATINA: NEOPYGMEPHORIDAE) FROM ARCTIC RUSSIA WITH DESCRIPTION OF A NEW SPECIES
}

\section{Alexander A. Khaustov ${ }^{1 *}$ and Olga L. Makarova ${ }^{2}$}

\author{
${ }^{1}$ Tyumen State University, Tyumen, Russia \\ ${ }^{2}$ Severtsov Institute for Problems of Ecology and Evolution, Russian Academy of Sciences, \\ Moscow, Russia \\ *corresponding author; e-mail: alex1973khaustov@gmail.com
}

\begin{abstract}
The genus Rackia Mahunka, 1975 (Acari: Pygmephoroidea: Neopygmephoridae) is recorded from Russia for the first time. A new species, Rackia curculionoides sp. n. is described from soil of the arctic Vaigach Island, the north of Eastern Siberia. A key to species of the genus Rackia is provided. It was suggested that the elongated gnathosomal capsule in Rackia curculionoides sp. $\mathrm{n}$. and other species of Rackia is a result of homoplasy.
\end{abstract}

KEY WORDS: Acarina, Pygmephoroidea, systematics, key, tundra.

DOI: 10.21684/0132-8077.2016.24.1.55.60

\section{INTRODUCTION}

The superfamily Pygmephoroidea Cross, 1965 includes four families: Pygmephoridae Cross, 1965; Neopygmephoridae Cross, 1965; Microdispidae Cross, 1965, and Scutacaridae Oudemans, 1916 together comprising more than 1200 species (Zhang et al. 2011). Probably all pygmephoroid mites are fungivorous (Khaustov 2008), but some species of the family Microdispidae might be parasitoids of insects (Kaliszewski et al. 1995). The family Neopygmephoridae includes 20 genera and more than 250 species (Zhang et al. 2011; Khaustov and Trach 2012, 2014).

The mite genus Rackia Mahunka, 1975 (Acari: Pygmephoroidea: Neopygmephoridae) includes 3 described species: $R$. miurai (Sasa, 1961) from Japan (Sasa 1961), R. sasai (Mahunka, 1970) from Hungary (Mahunka 1970) and R. acutifer Mahunka, 1975 from Slovenia (Mahunka 1975). During the study of mite fauna of Vaygach Island a new species of the genus Rackia was revealed. The aim of this paper is to describe a new species and provide the key to species of the genus Rackia.

\section{MATERIAL AND METHODS}

Mites were collected from soil samples using Berlese funnels and mounted in Hoyer's medium. The terminology of idiosoma and legs follows that of Lindquist (1986); the nomenclature of subcapitular setae and the designation of cheliceral setae are according to Grandjean (1944, 1947), respectively. The system conception of Pygmephoroidea follows Khaustov $(2004,2008)$. All measurements are given in micrometers $(\mu \mathrm{m})$. For leg chaetotaxy, the number of solenidia is given in parentheses. The type material is deposited in the mite collection of the Tyumen State University Museum of Zoology, Tyumen, Russia.

\section{SYSTEMATICS}

\section{Family Neopygmephoridae Cross, 1965}

Genus Rackia Mahunka, 1975

Type species: Rackia acutifer Mahunka, 1975 by original designation.

\section{Rackia curculionoides sp. $\mathrm{n}$.}

Figs. 1-4

Description. Female (Figs. 1-4). Length of idiosoma 325 (320-360), width 160 (155-175). Gnathosoma (Fig. 2B). Gnathosomal capsule extremely long, beak-like. Dorsally with 2 pairs of smooth, subequal setae (cha, chb) and a pair of postpalpal setae $(p p)$, situated posterolaterally to bases of chb. Dorsal median apodeme absent. Ventral gnathosoma with one pair of long subcapitular setae $(m)$. Palps freely articulated to gnathosomal capsule, with setae $d F e$ and $d G e$ dorsolaterally. Ventral palp surface with large accessory setigenous structure (ass) and small solenidion behind it. Palps without terminal claw. Pharyngeal pumps I-III grouped together on long oesophagus (Fig. 2A). Pharyngeal pumps I and III small; pharyngeal pump II large, about 3 times longer than pharyngeal pump III.

Idiosomal dorsum (Fig. 1A). Prodorsum not covered by anterior margin of tergite $\mathrm{C}$, with 2 pairs of setae $\left(v_{2}, s c_{2}\right)$, one pair of clavate and weakly barbed trichobothria $\left(s c_{1}\right)$ and one pair of round stigmata. All dorsal plates with numerous small dimples. Setae $v_{2}$ smooth, other dorsal setae dis- 


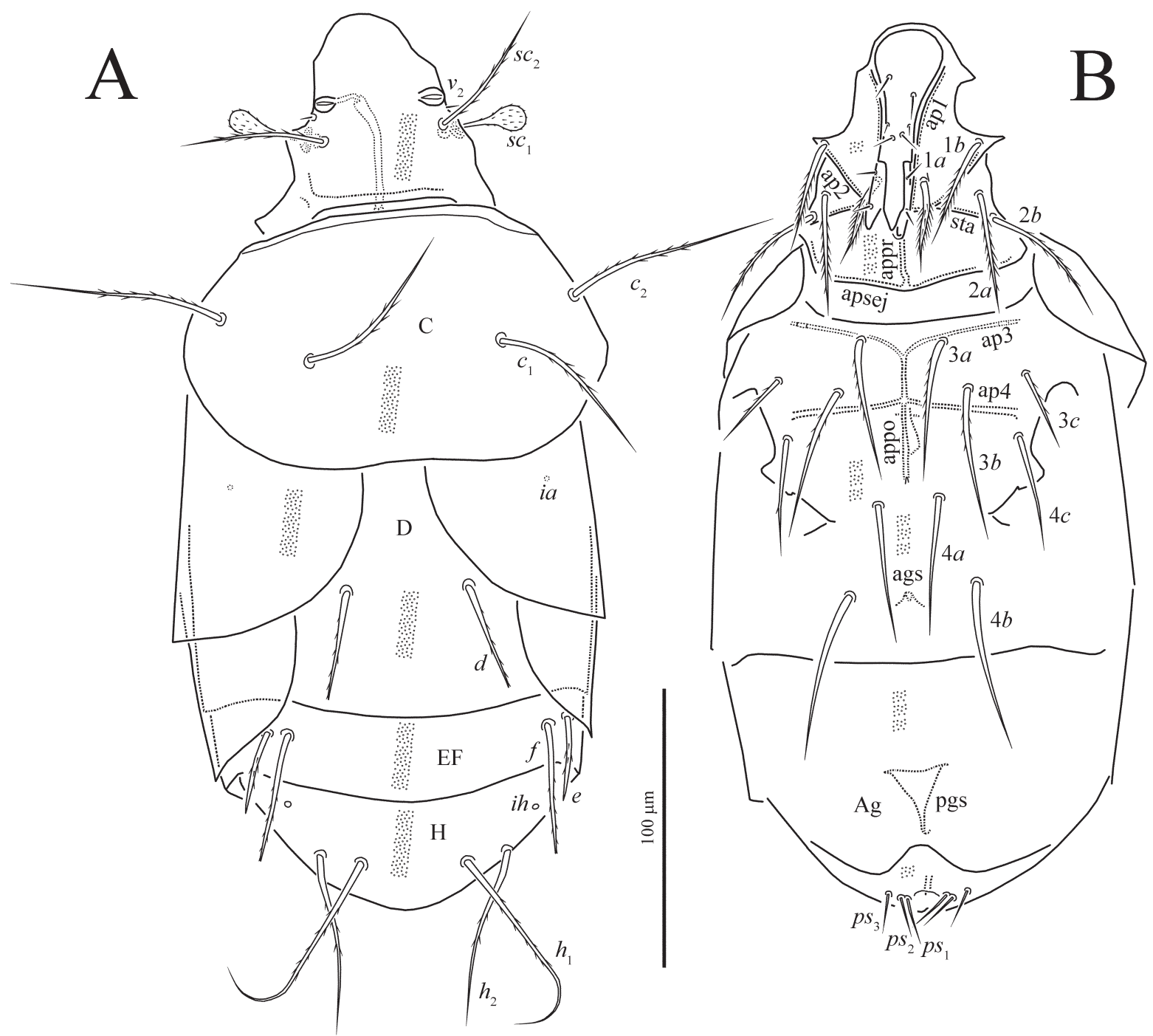

Fig. 1. Rackia curculionoides sp. n., female: A, B, dorsum and ventrum of idiosoma respectively.

tinctly barbed; setae $v_{2}, s c_{2}, c_{1}, c_{2}, h_{1}$, and $h_{2}$ pointed, other dorsal setae blunt-ended. Cupules $i a$ on tergite $\mathrm{D}$ and $i h$ on tergite $\mathrm{H}$ very small, round. Lengths of dorsal setae: $v_{2} 5(5-6), s c_{2} 57$ (55-60), $c_{1} 68$ (65-70), c $c_{2} 79$ (72-80), d 41 (39-42), e 31 (30-32), f50 (46-51), $h_{1} 84$ (76-86), $h_{2} 68(66-72)$. Distances between setae: $v_{2}-v_{2} 48(48-50), s c_{2}-s c_{2}$ 46 (45-47), $c_{1}-c_{1} 69$ (68-71), $c_{1}-c_{2} 37(36-39), d-d$ 43 (41-45), e-f 8 (7-9), f- $f 93$ (91-94), $h_{1}-h_{1} 39$ (39-44), $h_{1}-h_{2} 14$ (13-14).

Idiosomal venter (Fig. 1B). All ventral plates with numerous small dimples. Setae $4 a, 4 b, 4 c$, $p s_{1}-p s_{3}$ smooth, sometimes $4 c$ with 1 or 2 barbs. Apodemes 1 (ap1) well developed in distal part and indistinct proximally, not joined with prosternal apodeme (appr); apodemes 2 (ap2) well developed, joined with appr; prosternal and sejugal (apsej) apodemes well developed; secondary transverse apodemes (sta) consist of 2 oblique parts joined with ap2; apodemes 3 (ap3) long, straight, fused with poststernal apodeme (appo); apodemes 4 (ap4) well sclerotized and long, also fused with poststernal apodeme; apodemes 5 absent. Posterior margin of posterior sternal plate slightly convex in middle part. Posterior margin of aggenital plate deeply concave. Anterior genital sclerite (ags) bell-shaped, posterior genital sclerite (pgs) triangular. Lengths of ventral setae: $1 a 32$ (32-39), $1 b 41$ (40-47), $2 a$ 42 (42-54), $2 b 58$ (52-59), $3 a 51$ (50-54), 3 b 57 (57-60), 3c 29 (28-32), 4a 51 (50-54), $4 b 63$ (63-72), 4c 40 (39-43), $p s_{1} 18$ (16-20), ps 16 (14-17), ps 13 (12-14).

Legs (Figs. 3, 4). Leg I (Fig. 3A) slightly longer than leg II. Leg setation: 1-3-4-16(4). Tibiotarsus not thickened, with terminal claw situated on distinct pretarsus, clow tip thin. Lengths of solenidia: 

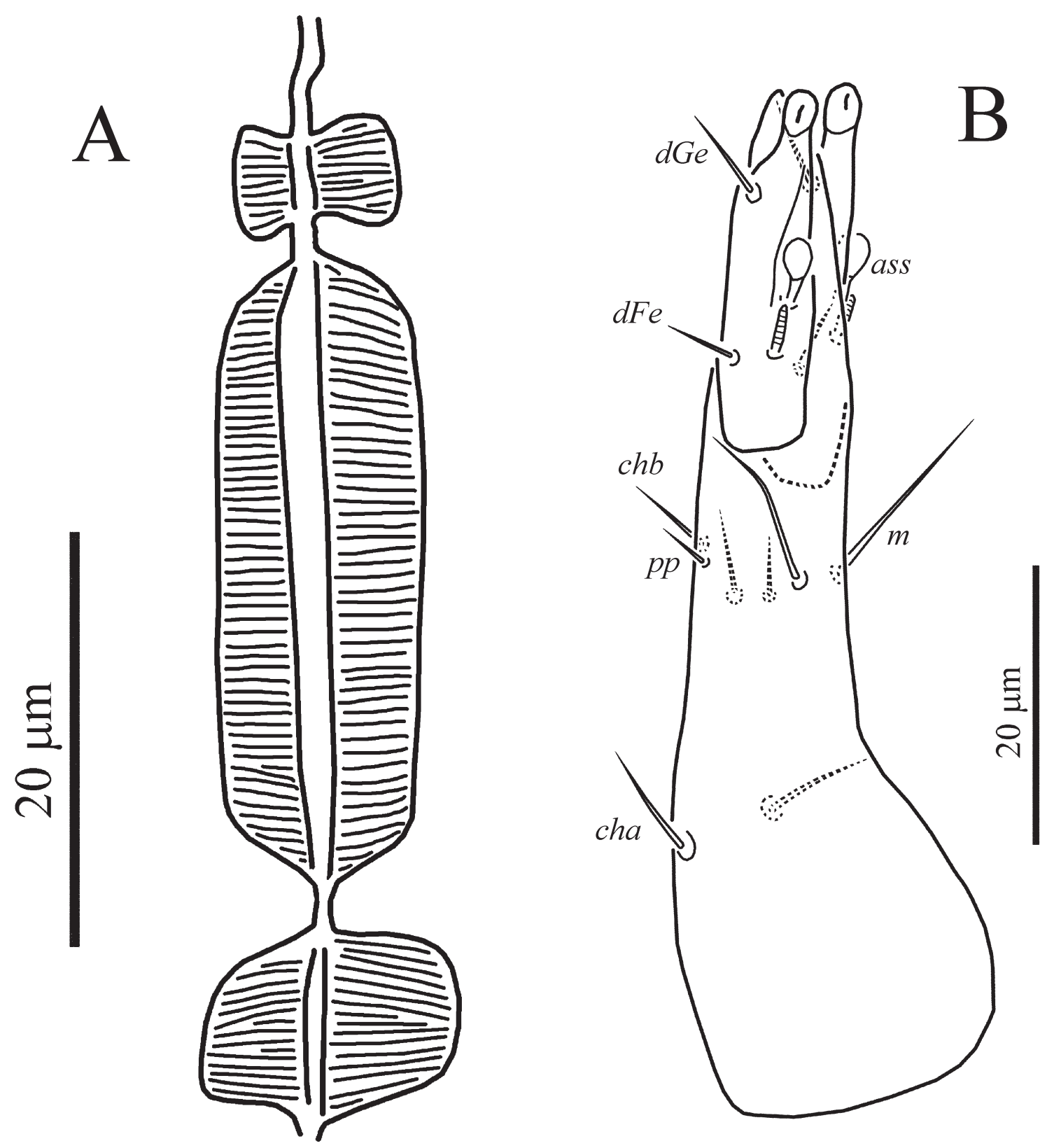

Fig. 2. Rackia curculionoides sp. n., female: A, pharynx; B, gnathosoma, ventrolateral aspect.

$\omega_{1} 25(23-27)>\omega_{2} 22(21-23)>\varphi_{1} 10(10-11)<$ $\varphi_{2} 16$ (16-20); $\omega_{2}$ and $\varphi_{2}$ uniformely thin, curved, $\omega_{1}$ and $\varphi_{1}$ finger-shaped. Setae $d F e$ broadened, hook-like. Seta l'Fe smooth, blunt-ended. Leg II (Fig. 3B). Leg setation: 1-3-3-4(1)-6(1). Tarsus with sickle-like, padded claws and relatively small empodium. Solenidion $\omega 20$ (19-21), fingershaped, solenidion $\varphi 7$ (7-8) finger-shaped. Setae $u$ ' blunt-ended and barbed in distal part. Leg III (Fig. 4A). Leg setation: 1-2-2-4(1)-6. Claws of same shape as on tarsus II. Solenidion $\varphi 6$ (6-7) finger-shaped. Setae $u$ 'blunt-ended and barbed in distal part. Leg IV (Fig. 4B) much longer than other legs. Leg setation: 1-2-1-4(1)-6. Tarsus relatively short, pretarsus short, with two small simple claws and small empodium. Solenidion $\varphi$ 4 (4-5), weakly clavate. Setae v'Ge and v' Ti bluntended. Setae $v$ " Ti smooth.

Male and larva unknown.

Type material. Female holotype, slide no OM220810, Russia: Nenets Autonomous Region, Vaygach Island, environs of Bolvanskaya Mt., $70^{\circ} 12^{\prime} 941^{\prime \prime} \mathrm{N}, 59^{\circ} 16^{\prime} 614^{\prime \prime} \mathrm{E}$, dwarf shrub-lichen stony tundra, in soil between hummocks, 22.08.2010, coll. B. Filippov, N. Zubrii. Paratypes: 17 females, same data as holotype. 


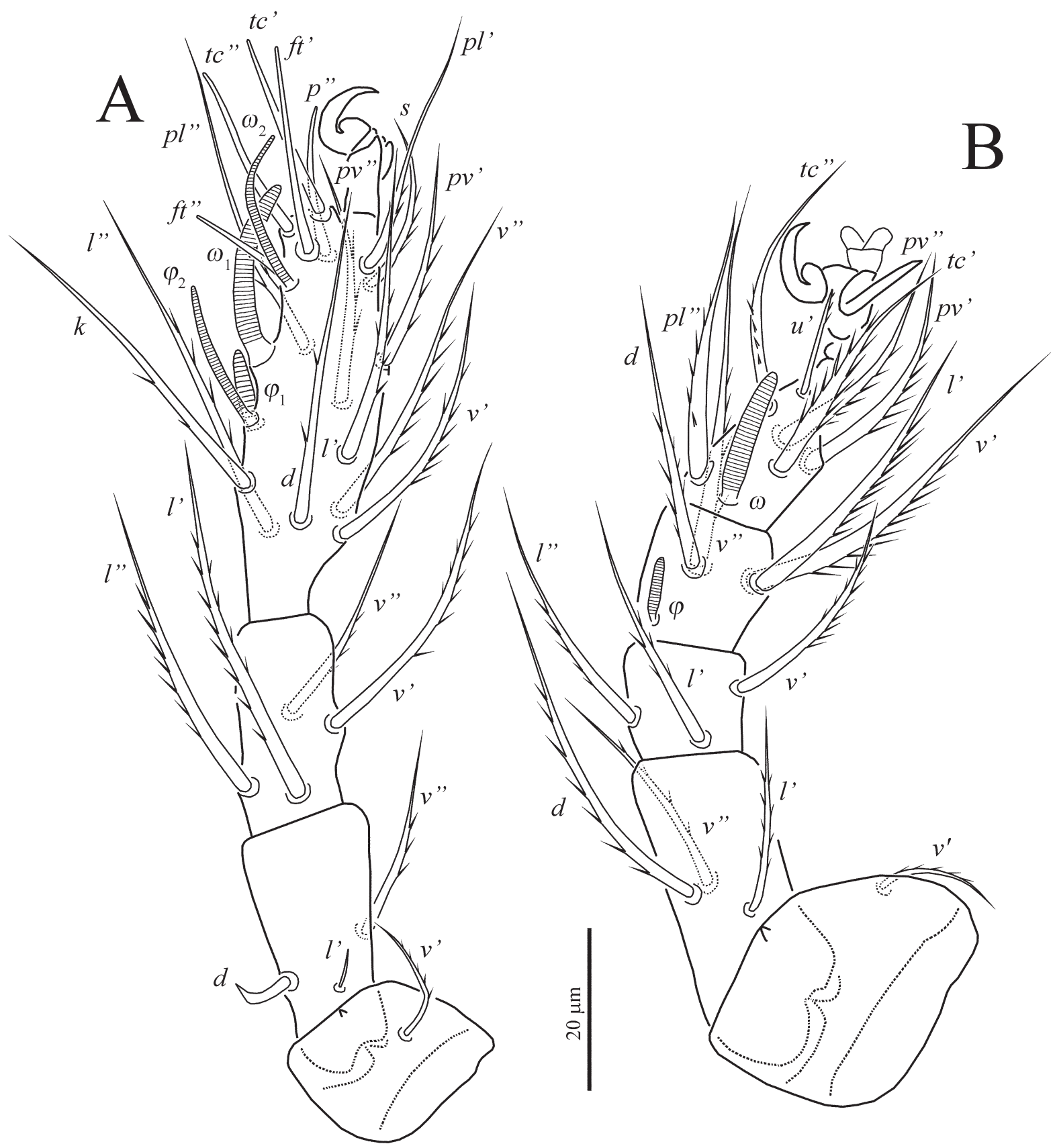

Fig. 3. Rackia curculionoides sp. n., female: A, B, legs I and II, respectively.

Etymology. The name of the new species referring to similarity of female gnathosoma to long and narrow head capsule of the curculionid beetles.

Differential diagnosis. The new species differs from all known Rackia-species by very short and smooth pseudanal setae (vs. at least $p s_{1}$ long and distinctly barbed in other species) and by relatively short and thick tarsus IV (vs. long and thin in other species).

\section{Key to species of the genus Rackia (females)}

1. At least one of paseudanal setae long and distinctly barbed, tarsus IV long and thin 2

- Paseudanal setae very short and smooth, tarsus IV short and thick............R. curculionoides sp. n.

2. All pseudanal setae subequal in length ........... 3

- Pseudanal setae $p s_{1}$ about 2 times longer than $p s_{2-3}$ …............................... R. miurai (Sasa, 1961)

3. Dosal setae $d$ distinctly shorter than $f$.

R. acutifer Mahunka, 1975 


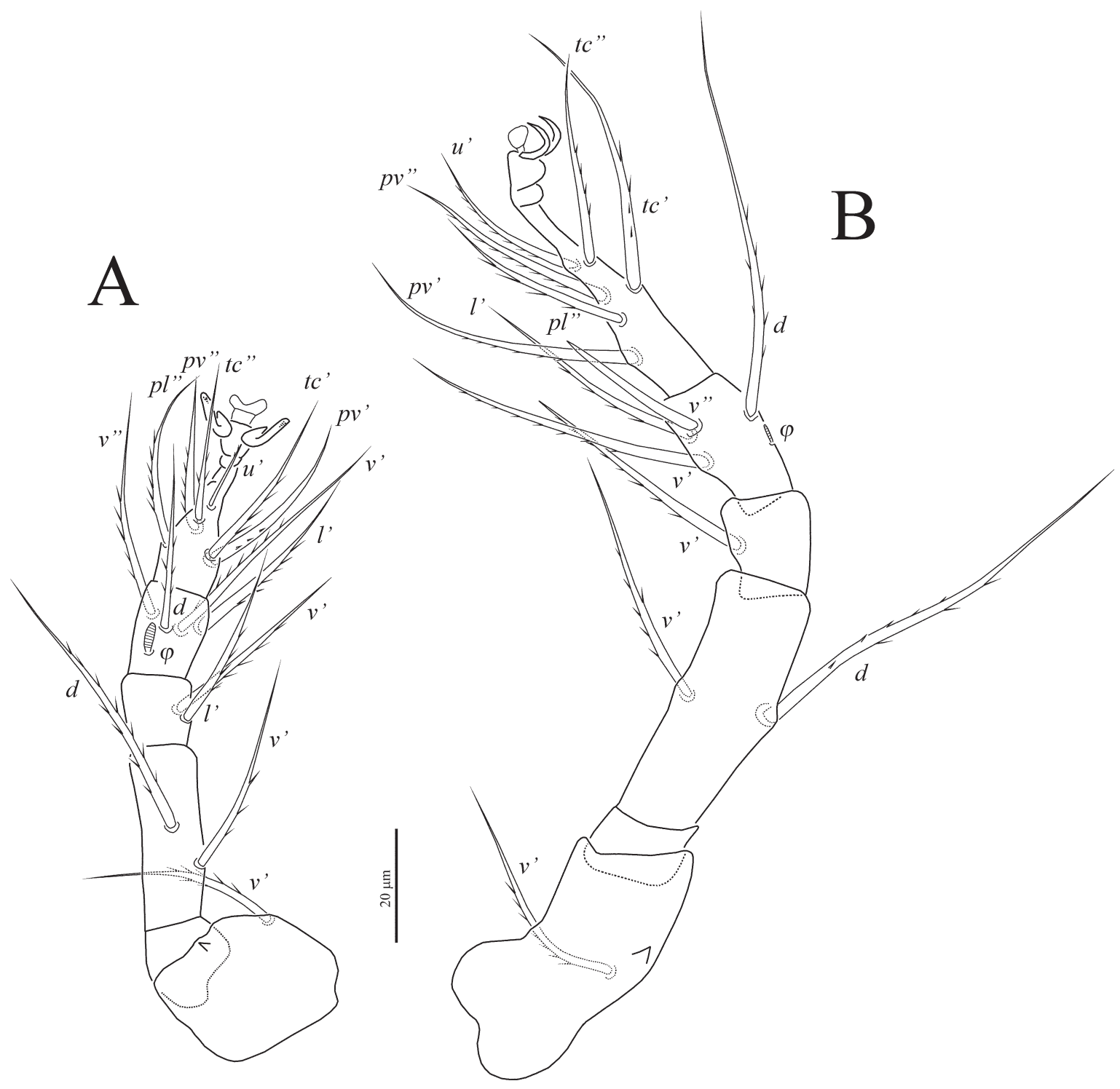

Fig. 4. Rackia curculionoides sp. n., female: A, B, legs III and IV, respectively.

- Dorsal setae $d$ distinctly longer than $f$. R. sasai (Mahunka, 1970)

\section{DISCUSSION}

The genus Rackia is characterized by the extremely long gnathosomal capsule of females. Similar elongation of gnathosomal capsule is known in many pygmephoroid genera, such as Rhynopygmephorus Kurosa, 2001 (Neopygmephoridae), Perperipes Cross, 1965, Glyphydomastax Cross, 1965 (Microdispidae), Rhynchodispus Mahunka, 1969, and Nasutiscutacarus Beer and Cross, 1960 (Scutacaridae). Undoubtedly, this structure is derived from the short and wide gnathosomal capsule independently in different lineages of Pygmephor- oidea. The purpose of such elongation of the gnathosomal capsule is unknown, but probably it is a result of high specialization to feeding by particular fungi. By the complex of other characters: the short and smooth pseudanal setae, relatively short and thick tarsus IV, very long femur IV, well developed oblique apodeme sta, the new species Rackia curculionoides $\mathrm{sp} . \mathrm{n}$. is more similar to species of the delaneyi-group of the genus Bakerdania Sasa, 1961 than to other species of the genus Rackia. With very high probability the elongated gnathosomal capsule in Rackia curculionoides sp. n. and other species of Rackia is a result of homoplasy. However, we retain new species within the genus Rackia given the phylogenetic relationships in the family Neopyg- 


\section{A. A. Khaustov and O. L. Makarova}

mephoridae as well as inside all known genera of this family remain unstudied.

\section{ACKNOWLEDGEMENTS}

The research of O.L. Makarova was supported by the Russian Foundation for Basic Research (no 14-04-01114). The authors are grateful to B.Yu. Filippov and N. Zubrii (North Arctic Federal University, Arkhangelsk) for sampling mite specimens. Preparation of these data for publication was conducted in the framework of the project "Mainstreaming the biodiversity and conservation into Russia's energy sector policies and operations" (no 00077026) of the United Nations Development Programme / Global Environment Facility-Minprirody of Russia (2014-2016).

\section{REFERENCES}

Grandjean, F. 1944. Observations sur les Acariens de la famille des Stigmaeidae. Archives des Sciences physiques et naturelles, 26: 103-131.

Grandjean, F. 1947. L'origine pileuse des mors et la chaetotaxie de la mandibule chez les Acariens actinochitineux. Comptes rendus des séances de l'Academie des Sciences, 224: 1251-1254.

Kaliszewski, M., Athias-Binche, F. and Lindquist, E.E. 1995. Parasitism and parasitoidism in Tarsonemina (Acari: Heterostigmata) and evolutionary considerations. Advances in Parasitology, 35: 335-367.

Khaustov, A.A. 2004. [Mites of the family Neopygmephoridae Cross, 1965 stat. $n$. and their position in Heterostigmata]. In: Y.S. Balashov (Ed.). VIII Russian Acarological Conference, St.-Petersburg. Zoological Institute of RAS, St.-Petersburg, p. 137. [in Russian]

Khaustov, A.A. 2008. Mites of the Family Scutacaridae of Eastern Palaearctic. Akademperiodyka, Kiev, $291 \mathrm{pp}$.
Khaustov, A.A. and Trach, V.A. 2012. A new genus and species of the family Neopygmephoridae (Acari: Heterostigmata: Pygmephoroidea) associated with Geotrupes spiniger (Coleoptera: Geotrupidae) from Ukraine. Acarina, 20: 3-7.

Khaustov, A.A. and Trach, V.A. 2014. Mites of the superfamily Pygmephoroidea (Acari: Heterostigmata: Neopygmephoridae, Pygmephoridae) associated with Trox cadaverinus (Coleoptera: Trogidae) from the Far East of Russia, with description of a new genus and two new species. Zootaxa, 3754: 86-96.

Lindquist, E.E. 1986. The world genera of Tarsonemidae (Acari: Heterostigmata): a morphological, phylogenetic, and systematic revision, with a reclassification of family-group taxa in the Heterostigmata. Memoirs of Entomological Society of Canada, 136: 1-517.

Mahunka, S. 1970. Considerations on the systematics of the Tarsonemina and the description of new European taxa (Acari: Trombidiformes). Acta Zoologica Academiae Scientiarum Hungaricae, 16: 137-174.

Mahunka, S. 1975. Beiträge zur Kenntnis der Tarsonemiden (Acari) von Kleinsäugernestern aus der Umgebung von Ljubljana (Jugoslawien). Parasitologia Hungarica, 8: 75-83.

Sasa, M. 1961. New mites of the genus Pygmephorus from small mammals in Japan (Acarina: Pyemotidae). Japanese Journal of Experimental Medicine, 31: 191-208.

Zhang, Z.-Q., Fan, Q.-H., Pesic, V., Smit, H., Bochkov, A.V., Khaustov, A.A., Baker, A., Wohltmann, A., Wen, T.-H., Amrine, J.W., Beron, P., Lin, J.-Z., Gabrys, G. and Husband, R. 2011. Order Trombidiformes Reuter, 1909. In: Zhang, Z-Q. (ed.) Animal biodiversity: an outline of higher-level classification and survey of taxonomic richness. Zootaxa, 3148: 129-138. 